\title{
The experimental study on the performances of the thermoelectric generator unit affected by heat rate of exhaust system
}

\author{
Hong Duc Thong ${ }^{1,2}{ }^{*}$, Nghiem Phan Thien Quan ${ }^{1,2}$, Mai Van Tinh ${ }^{1,2}$
}

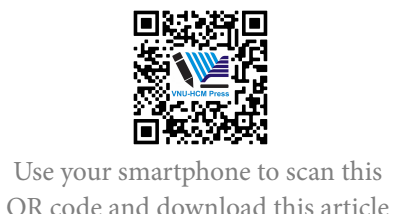

QR code and download this article

${ }^{l}$ Department of Automotive Engineering, Faculty of Transportation Engineering, Ho Chi Minh City University of Technology (HCMUT), Vietnam

${ }^{2}$ Vietnam National University Ho Chi Minh City (VNU-HCM), Vietnam

\section{Correspondence}

Hong Duc Thong, Department of Automotive Engineering, Faculty of Transportation Engineering, Ho Chi Minh City University of Technology (HCMUT), Vietnam

Vietnam National University Ho Chi Minh City (VNU-HCM), Vietnam

Email: hongducthong@hcmut.edu.vn

History

- Received: 20-8-2019

- Accepted: 30-12-2020

- Published: 22-01-2021

DOI : 10.32508/stdjet.v3iSI2.558

\section{Check for updates}

\section{Copyright}

( ) VNU-HCM Press. This is an openaccess article distributed under the terms of the Creative Commons Attribution 4.0 International license.

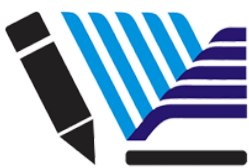

VNU-HCM Press

ABSTRACT

This study examines the effect of heat rate transferring from the exhaust system of motorcycle to the environment on the performance of the Thermoelectric Generator Unit (TGU). This heat rate is changed by attaching thermal insulation material on the outside of the exhaust system and changing the heat absorbing area of the TGU. The TGU consists of 8 thermoelectric generator modules and collects heat energy from the exhaust to produce electricity. It is attached on the custom muffler of the Suzuki Sapphire 125 and tested in the speed range from $20 \mathrm{~km} / \mathrm{h}$ to $50 \mathrm{~km} / \mathrm{h}$. The results show that this heat rate affects both the temperature and output power generated by the TGU. The reduction of this heat rate reduces the cool side temperature by limiting the warming effect of cooling air and raise the hot side temperature of the TGU by decreasing heat loss. These two effects lead to the increase of the temperature difference between both sides of the TGU and therefore the output power increases. The difference in output power between test cases can reach up to $54 \%$. Moreover, the heat loss at exhaust tube affects both temperature and output power of TGU from low to mid vehicle speed. However, at high speed, this heat loss at the exhaust tube does not considerably affect the output power of the TGU. To summarize, by reducing the heat rate between exhaust system and environment, the TGU can reach its stable working condition faster and produces more output power. Nonetheless, reducing this heat rate too much may lead to the excess of the hot side temperature of TGU, therefore damaging the thermoelectric generator modules and reducing the conversion efficiency of the TGU.

Key words: : Heat rate, temperature, output power, thermoelectric generator unit

\section{INTRODUCTION}

Today, environment pollution, traditional resource depletion, and energy security are important issues for all countries in the world. This has required people to find alternative energy sources or use efficiently for existing energy sources. In an internal combustion engine, about $30-40 \%$ of the energy of fuel generated from combustion is in exhaust gas ${ }^{1}$ and most of it is wasted directly into the environment. The recovery and reuse of this energy source have attracted the attention of researchers and many scientific works that have been carried out on the application of Thermoelectric Generator (TEG) ${ }^{2-22}$ using heat source from the exhaust gas of internal combustion engines.

In previous studies ${ }^{23-26}$, the authors conducted research and development of Thermoelectric Generator Unit (TGU) using heat source from motorcycle exhaust based on surveying the change in hot side temperature and cool side temperature through changing the structure of the Hot Side Heatsink (HSH) and the Cool Side Heatsink (CSH). In this study, the authors investigated the influence of heat rate on the operating characteristics of the TGU through the insulation of the exhaust system. The purpose of this study is to show the influence of heat rate on the hot side temperature, the cool side temperature, the temperature difference and the output power of the TGU. The research results have important value as a basis for optimizing the structure and improving the conversion efficiency of the TGU.

\section{BASIS OF THEORY}

Heat transferring through the exhaust system wall

On the exhaust system of the vehicle, there are two main types of heat transfer: conduction and convection. Convection takes place between the inner surface of the exhaust system and the exhaust gas; and between the outer surface of the exhaust system and the ambient air. Conduction takes place on the exhaust system wall.

Insulating the outer surface of the exhaust system changes the characteristics of the thermal convection between the exhaust system and the environment. Figure 1 shows the heat transfer process through the exhaust system wall when an external insulation layer and Technology; 3(SI2):SI24-SI36. 
is attached.

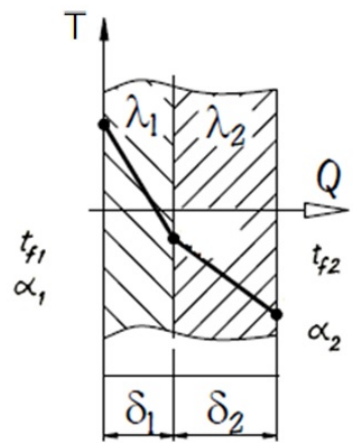

Figure 1: The process of heat transferring through an insulated exhaust system

The heat rate $Q(\mathrm{~W})$ is calculated according to the formula:

$$
Q=k \cdot F \cdot\left(t_{f 1}-t_{f 2}\right)
$$

With:

$$
k=\frac{1}{\frac{1}{\alpha_{1}}+\frac{\delta_{1}}{\lambda_{1}}+\frac{\delta_{2}}{\lambda_{2}}+\frac{1}{\alpha_{2}}}
$$

Where: $k\left(\mathrm{~W} / \mathrm{m}^{2} . \mathrm{K}\right)$ is the overall heat transfer coefficient; $\alpha_{1}$ and $\alpha_{2}(\mathrm{~W} / \mathrm{m} 2 . \mathrm{K})$ respectively are the convection heat transfer coefficient between the inner surface of the exhaust system and the exhaust gas, and between the outer surface of the exhaust system and the ambient air; $\delta_{1}$ and $\delta_{2}(\mathrm{~m})$ respectively are the thickness of the exhaust system wall and the heatinsulation layer; $\lambda_{1}$ and $\lambda_{2}(\mathrm{~W} / \mathrm{m} . \mathrm{K})$ respectively are the thermal conductivity coefficient of the material of the exhaust system and the insulation material; $\mathrm{F}\left(\mathrm{m}^{2}\right)$ is the heat transfer area; $t_{f 1}(\mathrm{~K})$ is the temperature of the exhaust gas; $t_{f 2}(\mathrm{~K})$ is the temperature of the ambient air.

\section{Seebeck effect}

Seebeck effect is the phenomenon that the thermal energy is converted directly into electrical energy in a closed - circuit consisting of two metallic conductors being weld together. It is called a closed - circuit thermocouple. The current is generated by the temperature difference between the two welds (Figure 2).

The voltage of this electrical current is calculated using the formula:

$$
U_{S}=S\left(T_{h}-T_{c}\right)=S . \triangle T
$$

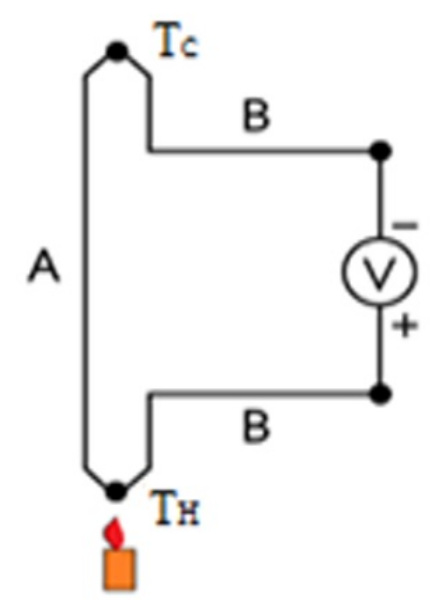

Figure 2: The closed - circuit thermocouple

Where: $S(\mathrm{~V} / \mathrm{K})$ is Seebeck coefficient; $T_{h}(\mathrm{~K})$ and $T_{c}$ $(\mathrm{K})$ are the temperatures of the hot side and the cool side, respectively; $\triangle T(\mathrm{~K})$ is the temperature difference between the hot side and the cool side.

\section{Thermoelectric generator - TEG}

The relationship between the output power $P(\mathrm{~W})$ and the heat rate $Q(\mathrm{~W})$ transferring through the TEG module is presented by the formula:

$$
P=\eta \cdot Q
$$

Thermal - electrical conversion efficiency $\eta$ is determined by the formula:

$$
\eta=\frac{\triangle T}{T_{h}} \cdot \frac{\sqrt{1+Z T}-1}{\sqrt{1+Z T}+T_{c} / T_{h}}
$$

Where: $\triangle T(\mathrm{~K})$ is the temperature difference between the hot side and the cool side of TEG module; $T(\mathrm{~K})$ is the average temperature of the hot side and cool side; and $Z(1 / \mathrm{K})$ is the quality factor of the thermoelectric material, presented by the formula:

$$
Z=\frac{S^{2}}{\lambda \rho}
$$

With: $S(\mathrm{~V} / \mathrm{K})$ is Seebeck coefficient; $\lambda(\mathrm{W} / \mathrm{m} . \mathrm{K})$ is the thermal conductivity coefficient of the material of the TEG module; and $\rho(\Omega . \mathrm{m})$ is resistivity.

Considering the circuit provides load (Figure 3) of TEG, we have the following equation:

$$
\begin{gathered}
U_{S}=E_{S}=S . \triangle T \\
I_{L}=\frac{E_{S}}{R_{i}+R_{L}}=\frac{S \triangle T}{R_{i}+R_{L}}
\end{gathered}
$$




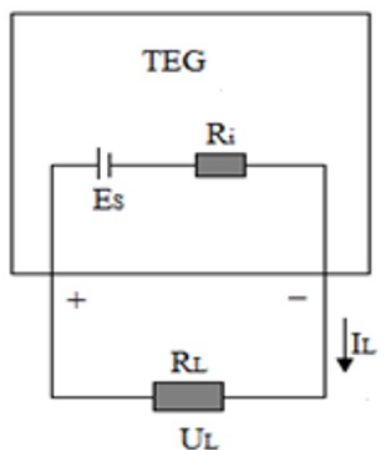

Figure 3: Mathematical model of TEG modules

$$
\begin{gathered}
U_{L}=I_{L} R_{L}=E_{S}-I_{L} R_{i} \\
Q_{\text {in }}=k_{t} \cdot \Delta T+S \cdot T_{h} \cdot I_{L}-0,5 \cdot R_{i} \cdot I_{L}^{2} \\
Q_{\text {out }}=k_{t} \cdot \triangle T+S \cdot T_{c} \cdot I_{L}-0,5 \cdot R_{i} \cdot I_{L}^{2} \\
P_{L}=I_{L} \cdot U_{L}=Q_{\text {in }}-Q_{\text {out }} \\
=S \cdot I_{L} \cdot \triangle T-R_{i} I_{L}^{2}
\end{gathered}
$$

Where: $E_{S}(\mathrm{~V})$ is the electromotive force of TEG; $U_{S}$ $(\mathrm{V})$ is the voltage generated by the Seebeck effect; $S$ $(\mathrm{V} / \mathrm{K})$ is Seebeck coefficient; $R_{i}(\Omega)$ is the resistance of the TEG; $R_{L}(\Omega)$ is the load resistor; $T_{h}(\mathrm{~K})$ is the temperature of the hot side; $T_{c}(\mathrm{~K})$ is the temperature of the cool side; $\triangle T(\mathrm{~K})$ is the temperature difference between the hot and cool side; $k_{t}(\mathrm{~W} / \mathrm{K})$ is the total thermal conductance of TEG; $P_{L}(\mathrm{~W})$ is the output power with load; $Q_{\text {in }}(\mathrm{W})$ is the heat input; $Q_{\text {out }}(\mathrm{W})$ is the heat output; $I_{L}(\mathrm{~A})$ is the amperage; $U_{L}(\mathrm{~V})$ is the voltage.

\section{RESEARCH MODEL}

\section{Thermoelectric Generator Unit - TGU}

The TGU's structure with muffler is shown in Figure 4, which includes: muffler (7) designed for Suzuki Sapphire 125 motorbike; the HSH (5); 08 TEP1-142T300 TEG modules connected in series (4); the CSH (1). In addition, the system has other components such as screws (3) and gasket (6) to connect the HSH (5) to the muffler (7); the nuts (2), the threaded rods (8), the washers (9) and the springs (10) for pressing the CSH (1), the TEG modules (4) and the HSH (5) together. Between the CSH (1) and the TEG modules (4), as well as between the TEG modules (4) and the HSH (5), there is a layer of thermal compound.
The TEG modules used in the model are type TEP1$142 \mathrm{~T} 300$ with dimensions of $40 \mathrm{~mm} \mathrm{x} 40 \mathrm{~mm} \mathrm{x}$ $3.8 \mathrm{~mm}$; and the maximum working temperature is $300^{\circ} \mathrm{C}$.

In this study, two aluminum HSHs are used with different quantity of fins: 21 fins and 12 fins; the $\mathrm{CSH}$ is made of aluminum with 11 fins. The structure of the HSHs and CSH are shown in Figures 5, 6 and 7.
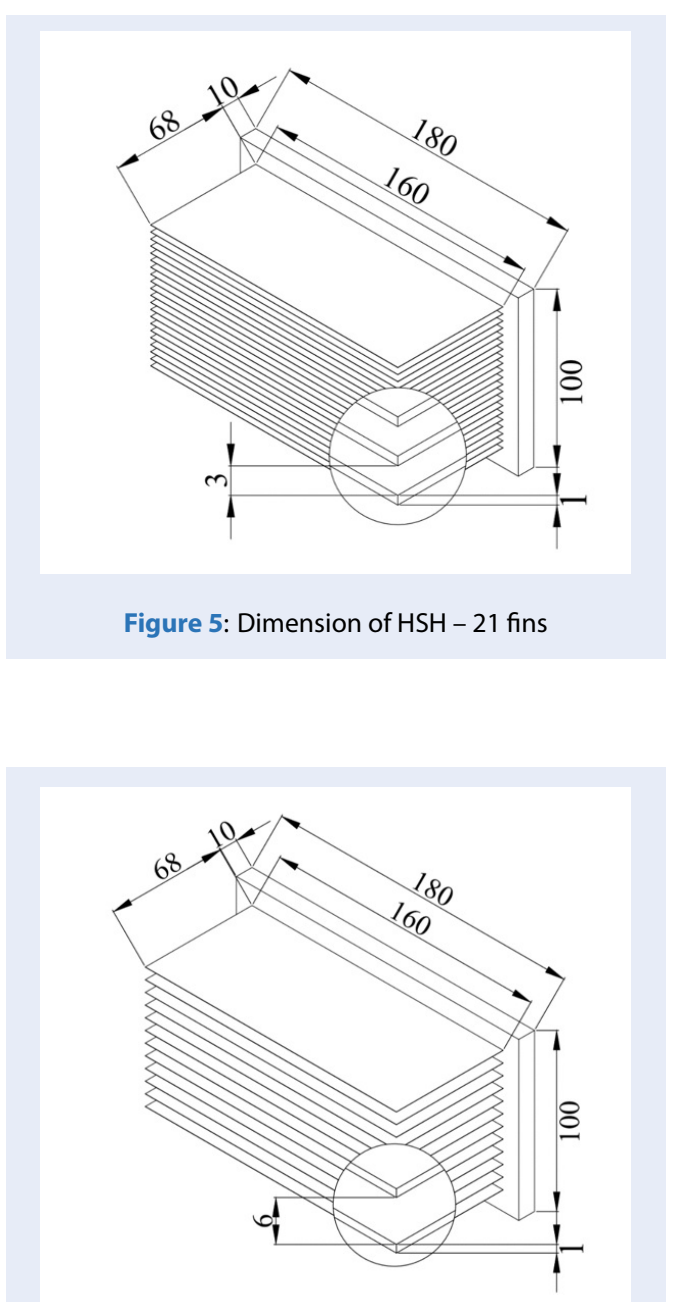

Figure 6: Dimension of $\mathrm{HSH}-12$ fins

To change the heat rate through the TGU, the authors change the $\mathrm{HSH}$ and insulate the exhaust system by fiberglass fabric (maximum working temperature: $500^{0} \mathrm{C}$; thermal conductivity coefficient $\lambda: 0.027$ $-0.04 \mathrm{~W} / \mathrm{m} . \mathrm{K})$ to investigate the characteristics of the TGU.

\section{Experiment description}

The diagram of the experimental system is shown in Figure 8 . To investigate the operating characteristics 


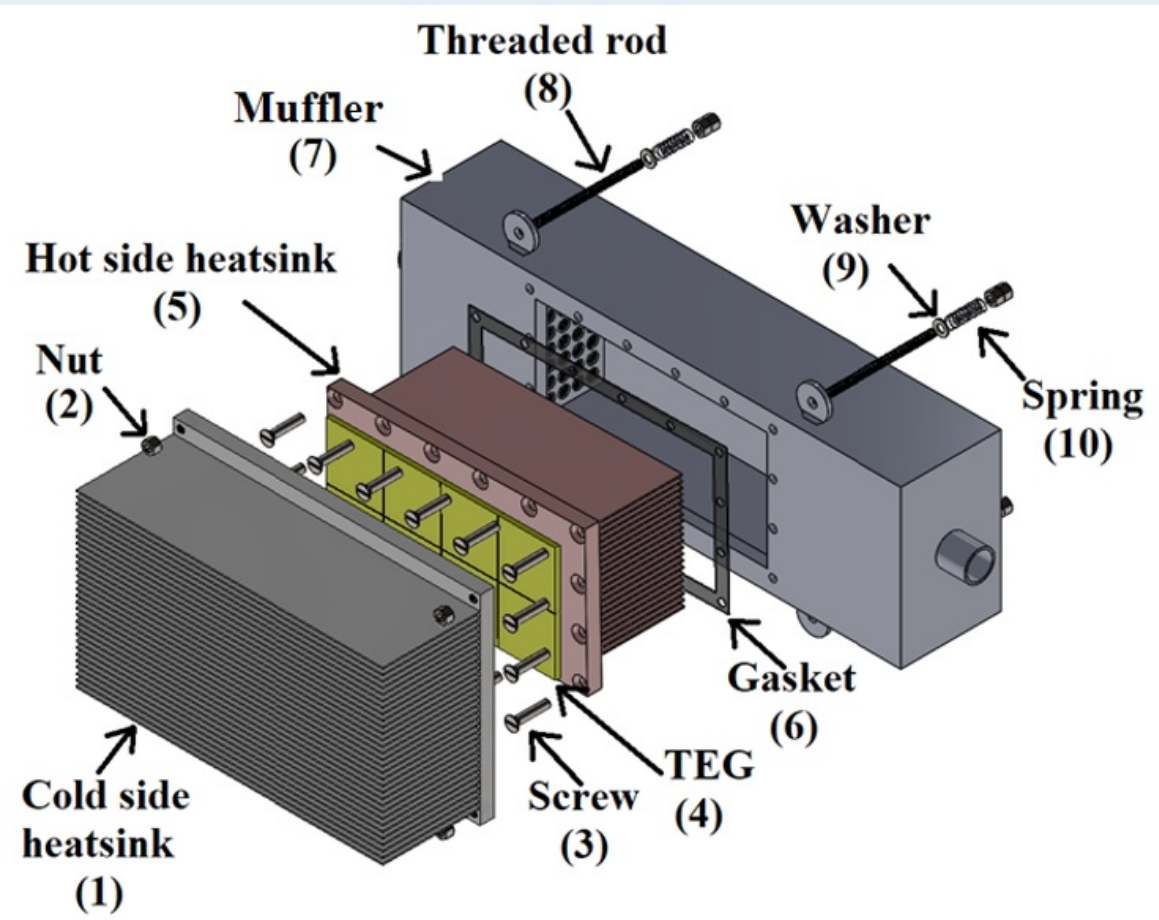

Figure 4: Structure of the TGU with muffler

Table 1: The parameters of sensors

\begin{tabular}{lllll}
\hline No. & Device & Type & Range & Accuracy \\
1 & Temperature sensor & RTD PT100 type B & $-50^{0} \mathrm{C}$ to $500^{0} \mathrm{C}$ & $\pm 0.2^{0} \mathrm{C}$ \\
2 & Infrared sensor & V1 & $2 \mathrm{~cm}$ to $5 \mathrm{~cm}$ & - \\
\hline
\end{tabular}

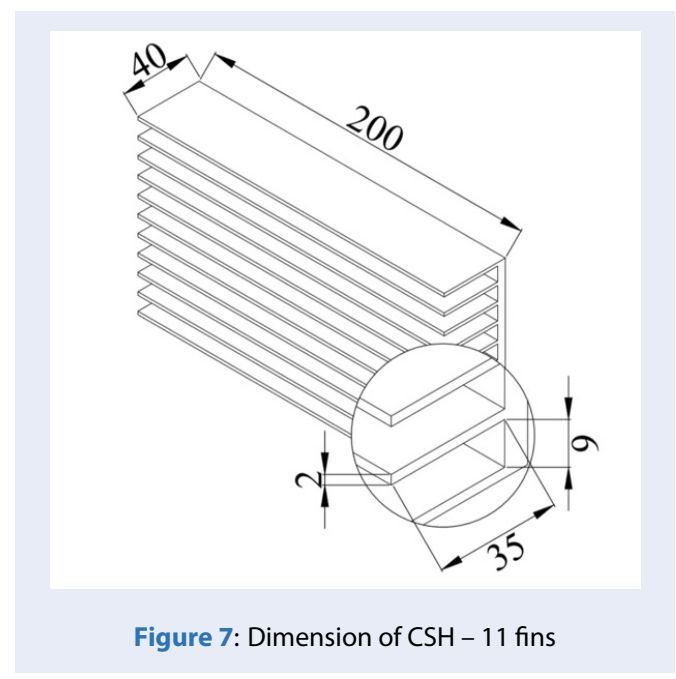

of the TGU, the data collection system will record the values including hot side temperature, cool side temperature, voltage, current of the TGU; and speed of the vehicle. The temperature sensors used are RTD PT100 type B (4 mm in probe diameter, $30 \mathrm{~mm}$ in probe length). In that, 02 sensors are located on 02 different points of the $\mathrm{HSH}$ to measure the temperature of the HSH; the other 02 sensors are located on the $\mathrm{CSH}$, which is symmetrical with 02 sensors on the $\mathrm{HSH}$, to measure the temperatures of the $\mathrm{CSH}$. The average temperature of the two sides is calculated by averaging the temperature value of the two sensors on those sides.

Voltage and current are measured by an integrated circuit (power circuit) operating in the ADC method (Analog-to-digital converter, the input voltage is converted to the numerical value to represent the magnitude of voltage, the current is calculated based on the initial resistance value and the voltage value). Vehicle speed is measured by an infrared sensor (V1) by 
measuring the speed of the front wheel. Characteristic values obtained by the data collection system are transmitted directly to the laptop via Bluetooth connection in real-time. The parameters of the temperature sensors and the infrared sensors are shown in Table 1.

The TGU installed on Suzuki Sapphire 125 (Figure 9) is tested on urban roads at stable speed modes of 20 , 30,40 and $50 \mathrm{~km} / \mathrm{h}$ with a load of 2 peoples. The time duration for investigating at each mode is 15 minutes, of which the first 10 minutes is used to achieve the temperature stabilization state and the 5 remain minutes is used to collect the device's parameters.

The test cases are shown in Table 2. The actual images of the TGU before and after insulation are shown in Figures 10 and 11.

Figure 12 and Figure 13 compare the hot side temperature, the cool side temperature, the temperature difference between the hot and cool side, and the output power of cases (1) and (3).

The results in Figure 12 shows that the hot side temperature in the case of heat-insulating is always higher than in the case of non-heat-insulating. This is explained by the fact that insulating the exhaust system helps reduce the heat loss and increase the heat rate which is absorbed by the HSH. At $50 \mathrm{~km} / \mathrm{h}$, the hot side temperature of case (3) and case (1) are $215^{\circ} \mathrm{C}$ and $185.7^{\circ} \mathrm{C}$, respectively. In the speed range from 20 $\mathrm{km} / \mathrm{h}$ to $40 \mathrm{~km} / \mathrm{h}$, the cool side temperature of case (3) does not seem to change. Meanwhile, the cool side temperature of case (1) increases gradually. This is due to insulating the exhaust system helps reduce the warming phenomenon of the cooling air which flows through the CSH by the effect of heat loss. Therefore, the cooling capability of the CSH increases.

Figure 13 shows that the output power of case (3) is always higher than that of case (1) due to the higher temperature difference. At $50 \mathrm{~km} / \mathrm{h}$, the maximum output power of case (1) and case (3) are $5.37 \mathrm{~W}$ and $8.28 \mathrm{~W}$, respectively. As the speed increases, the output power of case (3) increases faster than that of case (1). Specifically, as the speed increases from $20 \mathrm{~km} / \mathrm{h}$ to $50 \mathrm{~km} / \mathrm{h}$, the output power of case (1) increases up to $233.5 \%$ (from $1.61 \mathrm{~W}$ to $5.37 \mathrm{~W}$ ) and the output power of case (3) increases up to $314 \%$ (from $2 \mathrm{~W}$ to $8.28 \mathrm{~W})$. This is explained by the fact that the higher increase in the temperature difference of case (3), resulting from absorbing more heat and better cooling capability when insulating the exhaust system.

Figure 14 and Figure 15 compare the hot side temperature, the cool side temperature, the temperature difference between the hot and cool side, and the output power of cases (2) and (3).
The results in Figure 14 show that the hot side temperature of case (2) is lower than that of case (3) due to heat loss at the exhaust tube. From $40 \mathrm{~km} / \mathrm{h}$, the hot side and cool side temperature of case (3) increase slower than those of case (2). This is explained by the fact that the heat rate, which is absorbed by the HSH, increases considerably when insulating all the exhaust system. Therefore, the TGU reaches the heat saturation state faster and the temperature increases slower. Figure 15 shows that the output power of case (3) is higher than that of case (2) due to the higher temperature difference. In the speed range from $30 \mathrm{~km} / \mathrm{h}$ to 40 $\mathrm{km} / \mathrm{h}$, the average difference of output power between 2 cases is $0.6 \mathrm{~W}$. However, as the speed increases, this difference decreases to $0.28 \mathrm{~W}$ at $50 \mathrm{~km} / \mathrm{h}$.

Figure 16 and Figure 17 compare the hot side temperature, the cool side temperature, the temperature difference between the hot and cool side, and the output power of cases (3) and (4).

The results in Figure 16 show that the hot side temperature of case (3) is considerably higher than that of case (4) due to larger fin quantity (21 fins and 12 fins, respectively). At $50 \mathrm{~km} / \mathrm{h}$, the difference in hot side temperature between 2 cases is $18.8^{\circ} \mathrm{C}$. Meanwhile, the cool side temperature of the 2 cases is not considerably different because the cooling capability of the $\mathrm{CSH}$ is substantially larger than the heat rate which is absorbed by the HSH.

Figure 17 shows that the temperature difference between the hot side and cool side of 2 cases are considerably different. At $50 \mathrm{~km} / \mathrm{h}$, the temperature difference of case (3) and case (4) are $116^{\circ} \mathrm{C}$ and $103^{\circ} \mathrm{C}$, respectively. In the speed range from $20 \mathrm{~km} / \mathrm{h}$ to 40 $\mathrm{km} / \mathrm{h}$, the output power of case (3) is higher than that of case (4). However, as the speed is greater than 40 $\mathrm{km} / \mathrm{h}$, the output power of case (4) is higher. At 50 $\mathrm{km} / \mathrm{h}$, the output power of case (3) and case (4) are $8.28 \mathrm{~W}$ and $8.87 \mathrm{~W}$, respectively. This is explained by the fact that if the hot side temperature is too high, it may lead to a decrease in conversion efficiency of TEGs. Then the output power will increase slower, especially in the case (3).

\section{CONCLUSIONS}

This study examines the effect of heat rate transferring from the exhaust system to the environment on the performance of the thermoelectric generator unit (TGU) by insulating the exhaust system. The work results in the conclusion as follows:

- The heat transfer between the surface of the exhaust system and the environment affects the characteristics of the hot side and the cool side of 


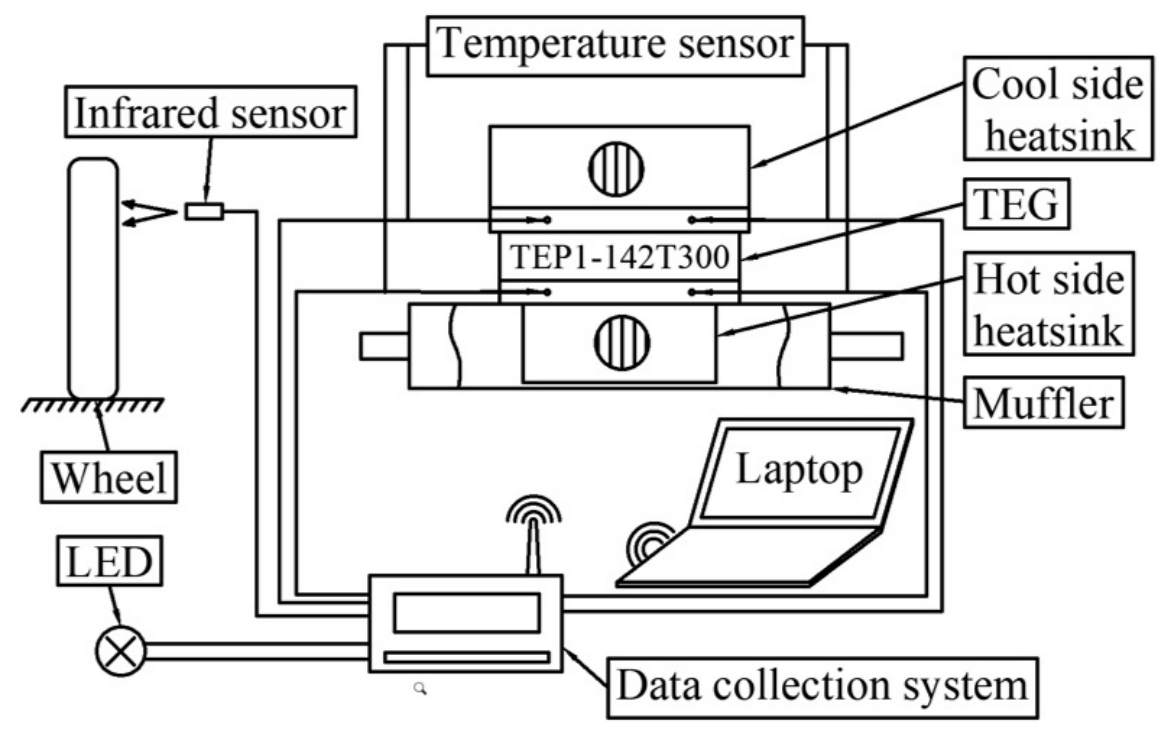

Figure 8: The diagram of the experimental system

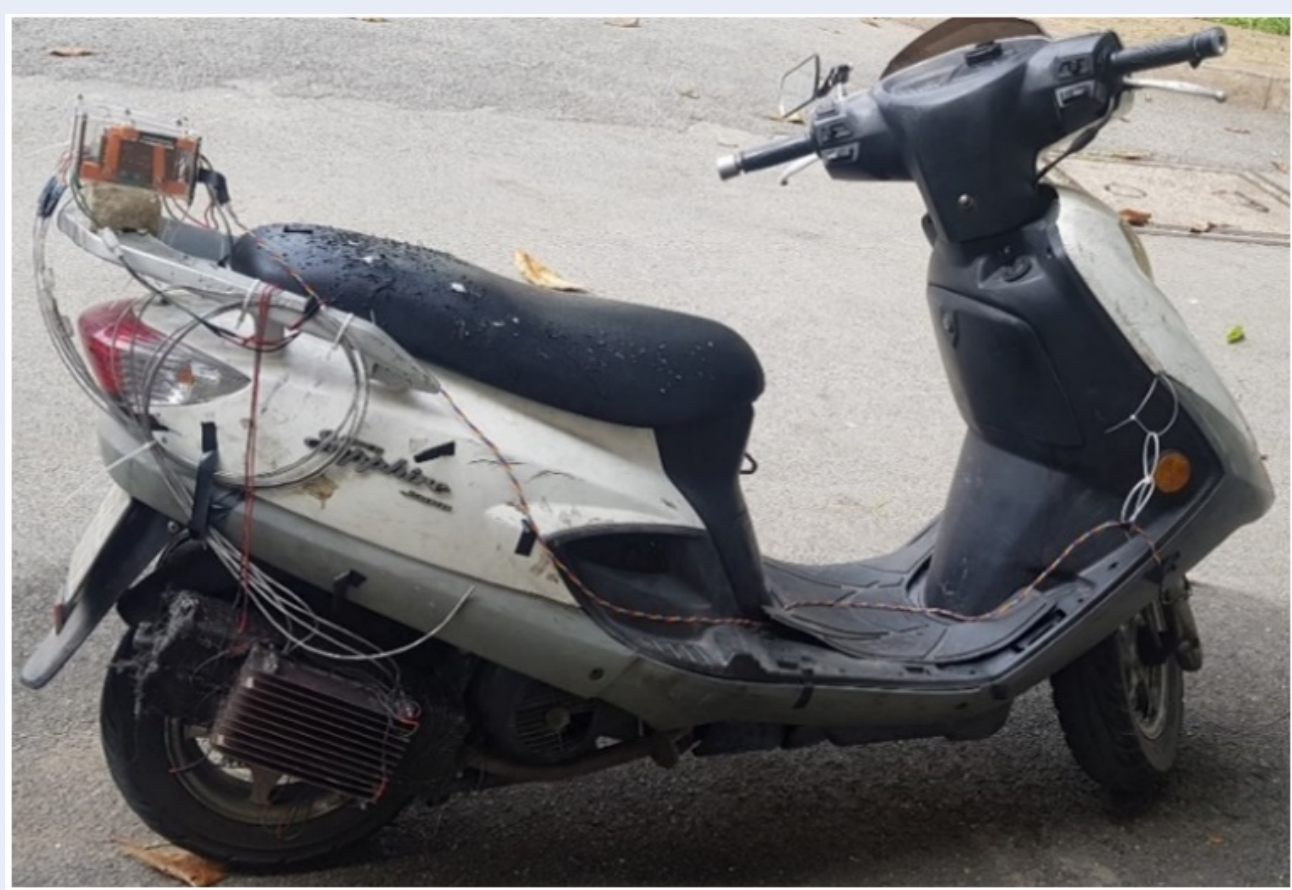

Figure 9: The TGU is installed on the vehicle 


\section{Table 2: Test Cases}

\begin{tabular}{lll|l}
\hline Cases & Characteristics & Quantity of fin of the HSH & Insulation thickness \\
$(1)$ & No insulation & 21 & - \\
$(2)$ & Insulate the muffler & 21 & $1 \mathrm{~mm}$ \\
$(3)$ & Insulate the exhaust system & 21 & $1 \mathrm{~mm}$ \\
$(4)$ & Insulate the exhaust system & 12 & $1 \mathrm{~mm}$ \\
\hline
\end{tabular}

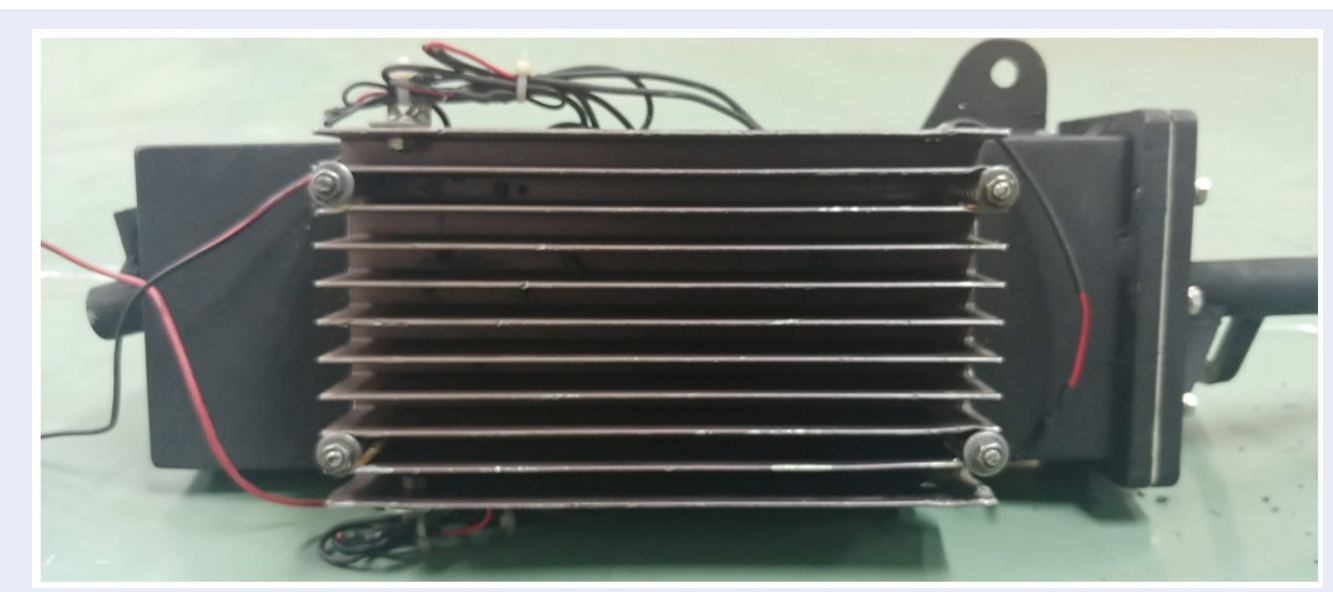

Figure 10: The TGU before insulating

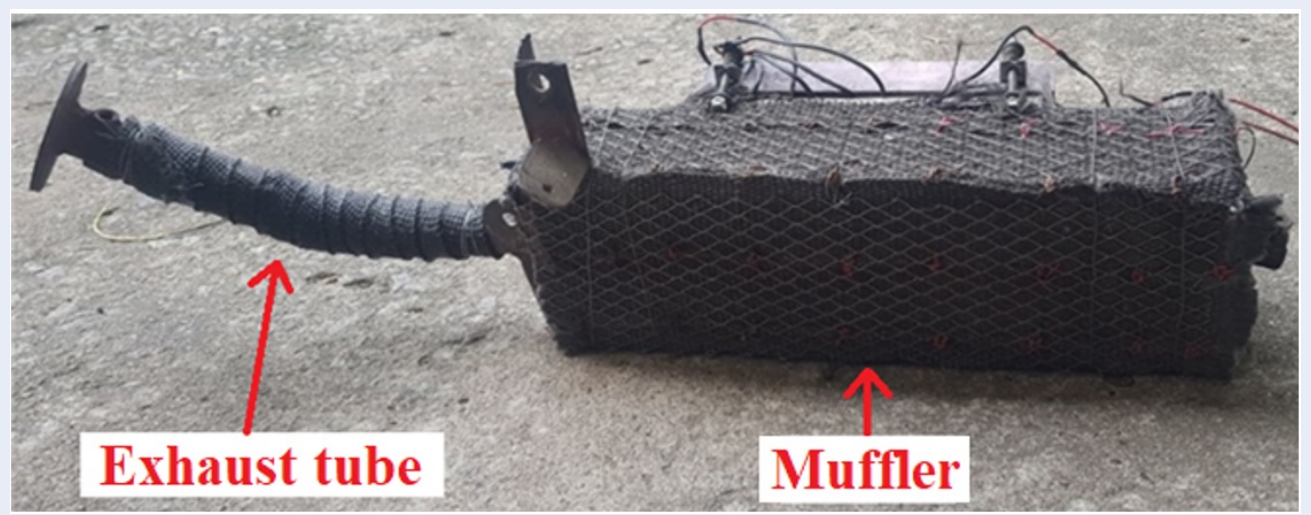

Figure 11: The TGU after insulating the exhaust system

the TGU. By insulating the outside surface of the exhaust system, the heat loss reduces. Therefore, the hot side heatsink absorbs more heat energy and it leads to the increase of hot side temperature. Besides that, insulating the exhaust system helps reduce the warming phenomenon of the cooling air by the effect of heat loss. Thus, the cooling capability of the cool side heatsink increases. The output power of the TGU increases considerably when insulating the exhaust sys- tem. Specifically, at $50 \mathrm{~km} / \mathrm{h}$, the difference in output power between the case of insulating and non-insulating is $54.2 \%$.

- By insulating the exhaust system, the heat loss reduces. Therefore, the TGU will reach to the heat saturation state faster.

- The output power does not only depend on the temperature difference between the hot side and the cool side of the TGU. If the hot side temperature is too high, the conversion efficiency of 


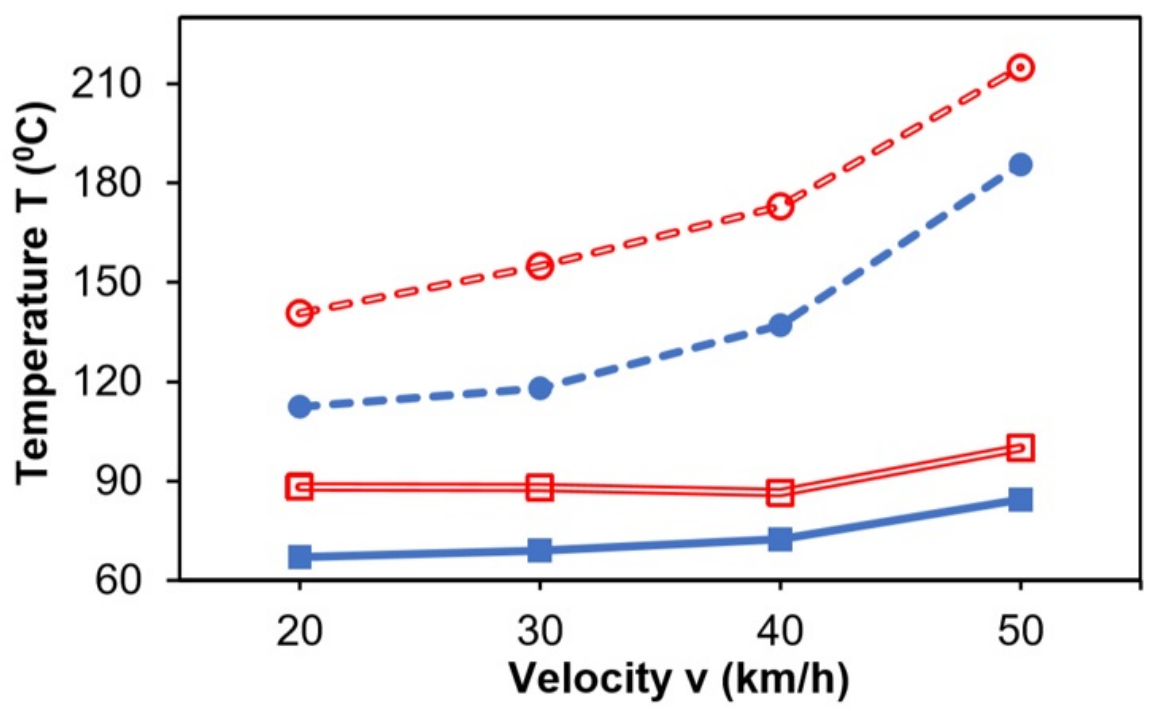

$\rightarrow-$ Hot side - Case 1

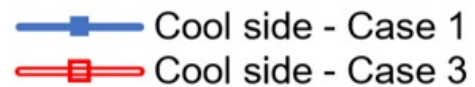

Figure 12: Characteristics of hot side temperature and cool side temperature correspond to vehicle speed in case (1) and case (3)
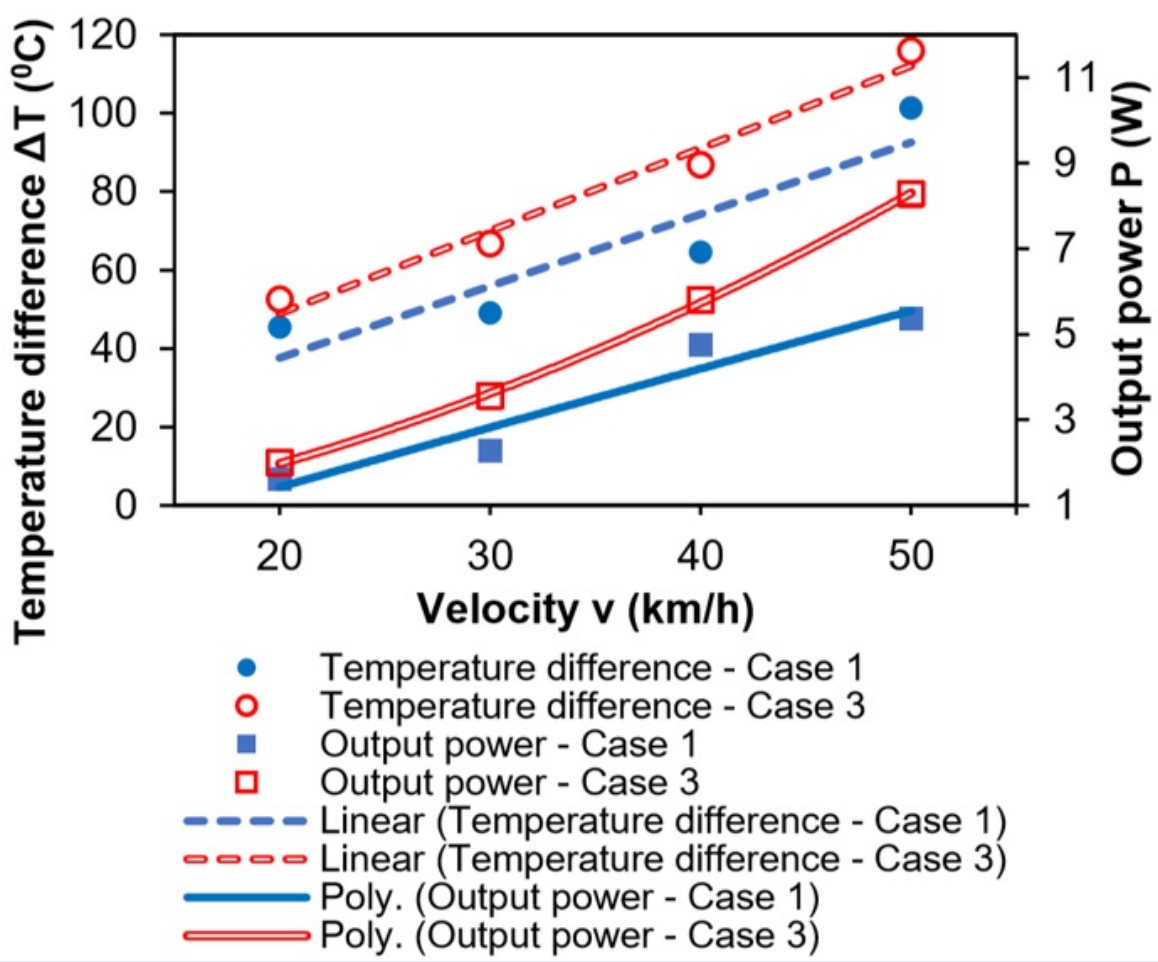

Figure 13: Characteristics of output power and temperature difference between the hot and cool side correspond to vehicle speed in case (1) and case (3) 


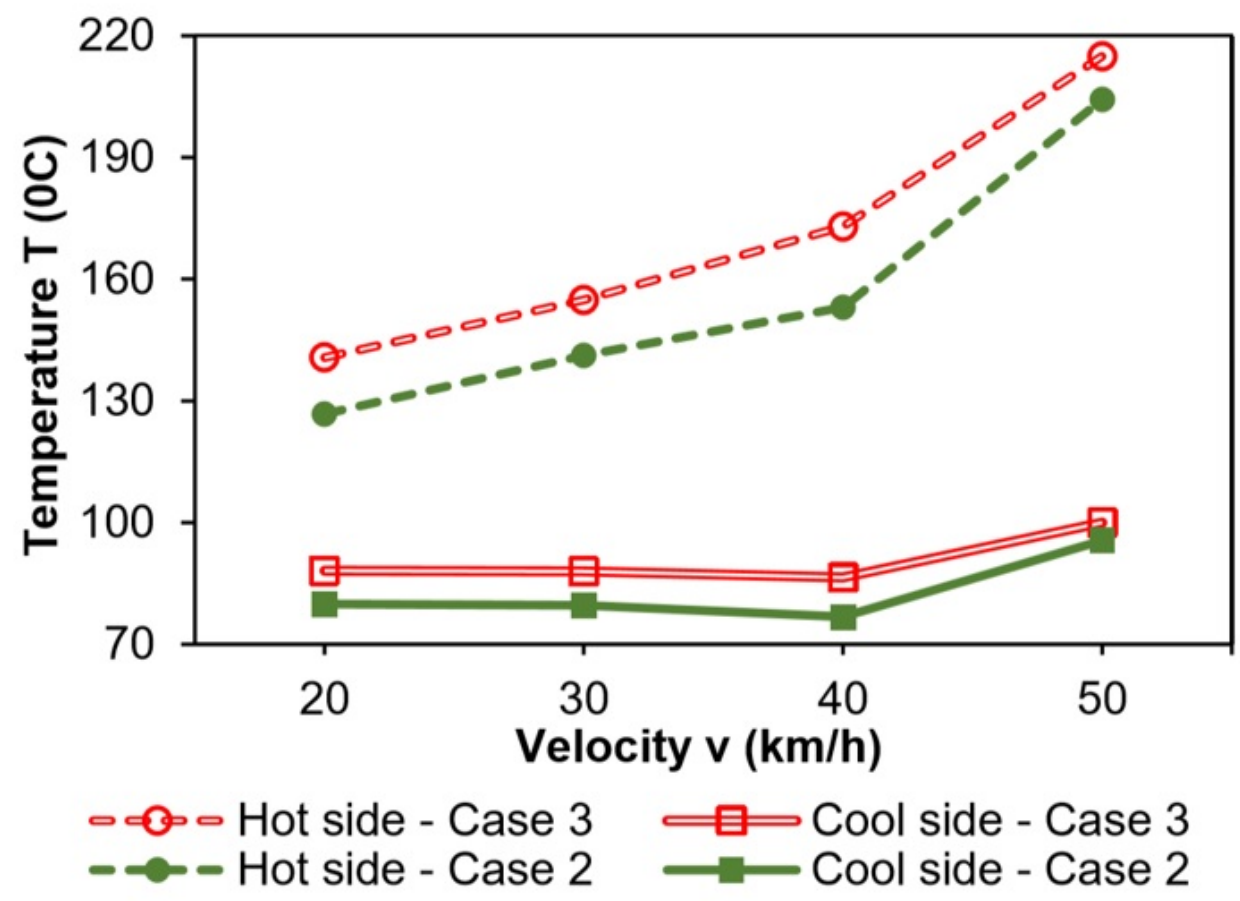

Figure 14: Characteristics of hot side temperature and cool side temperature correspond to vehicle speed in case (2) and case (3)

thermoelectric generators will decrease. Thus, the output power may increase slower despite the high-temperature difference.

\section{ABBREVIATIONS}

TGU: Thermoelectric Generator Unit

TEG: ThermoElectric Generator

HSH: Hot Side Heatsink

CSH: Cool Side Heatsink

\section{CONFLICTS OF INTEREST}

The authors declare that they have no conflicts of interest.

\section{AUTHOR CONTRIBUTIONS}

The contributions of each author in this paper are listed as below:

- Hong Duc Thong contributes in the supervision, project administration, supporting the experiment process and writing \& editing the paper.

- Nghiem Phan Thien Quan contributes in conducting the research and investigation process, analyzing the data and writing the manuscript of paper.

- Mai Van Tinh contributes in conducting the research and investigation process, analyzing the data and writing the manuscript of paper.

\section{ACKNOWLEDGMENTS}

This research is funded by Ho Chi Minh City University of Technology (HCMUT) under grant number TKTGT-2019-35. We acknowledge the support of time and facilities from Ho Chi Minh City University of Technology (HCMUT), VNU-HCM for this study.

\section{REFERENCES}

1. Stabler F. Automotive Thermoelectric Generator Design Issues. DOE Thermoelectric Applications Workshop, San Diego, CA. 2011;

2. Bass JC, Elsner NC, Leavitt FA. Performance of the $1 \mathrm{~kW}$ thermoelectric generator for diesel engine. Proceedings of the 13th international conference on thermoelectrics, New York. 1995;Available from: https://doi.org/10.1063/1.46818.

3. Ikoma K, Munekiyo M, Furuya K, Kobayashi M, Komatsu $H_{\text {, }}$ Shinohara K. Thermoelectric Generator for Gasoline Engine Vehicles Using Bi2Te3 Modules. J. Japan Inst. Metals. 1999;63:1475-1478. Available from: https://doi.org/10.2320/ jinstmet1952.63.11_1475.

4. Crane DT, Jackson GS. Optimization of cross flow heat exchangers for thermoelectric waste heat recovery. Energy Conversion and Management. 2004;45:1565-1582. Available from: https://doi.org/10.1016/j.enconman.2003.09.003.

5. LaGrandeur J. Automotive Waste Heat Conversion to Electric Power using Skutterudites, TAGS, PbTe and Bi2Te3. in Diesel Engine-Efficiency and Emission Research (DEER), Detroit MI. 2006;Available from: https://doi.org/10.1109/ICT. 2006.331220. 


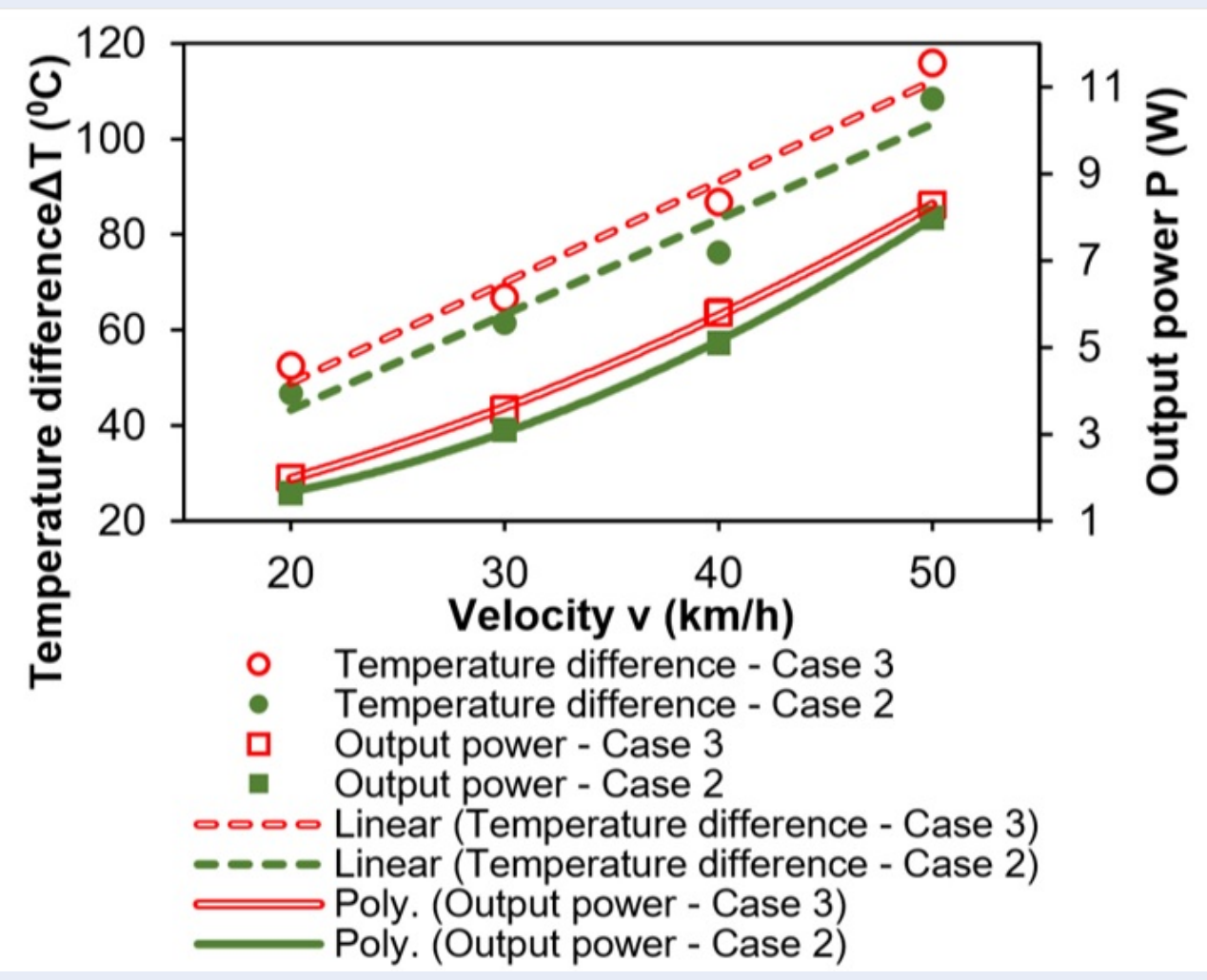

Figure 15: Characteristics of output power and temperature difference between the hot and cool side correspond to vehicle speed in case (2) and case (3)

6. Husain QE, Brigham DR, Maranville CW. Thermoelectric Exhaust Heat Recovery for Hybrid Vehicles. SAE Int. J. Engines. 2009;2(1):1132-1142. Available from: https://doi.org/10.4271/ 2009-01-1327.

7. Espinosa N, Lazard M, Aixala L, Scherrer H. Modeling a Thermoelectric Generator Applied to Diesel Automotive Heat Recovery. Journal of Electronic Materials. 2010;39:1446-1455. Available from: https://doi.org/10.1007/s11664-010-1305-2.

8. Hsu CT, Huang GT, Chu HT, Yu B, Yao DJ. Experiments and simulations on low-temperature waste heat harvesting system by thermoelectric power generators. Applied Energy. 2011;88:1191-1197. Available from: https://doi.org/10.1016/ j.apenergy.2010.10.005.

9. Mori M, Yamagami T, Sorazawa M, Miyabe T, Takahashi S, Haraguchi T. Simulation of Fuel Economy Effectiveness of Exhaust Heat Recovery System Using Thermoelectric Generator in a Series Hybrid. SAE Int. J. Mater. Manuf. 2011;4(1):12681276. Available from: https://doi.org/10.4271/2011-01-1335.

10. Meisner GP. Thermoelectric Conversion of Exhaust Gas Waste Heat into Usable Electricity. in Directions in Engine-Efficiency and Emissions Research (DEER) Conference, Detroit, Michigan. 2011;

11. Kim SK, Won BC, Rhi SH, Kim SH, Yoo JH, Jang JC. Thermoelectric Power Generation System for Future Hybrid Vehicles Using Hot Exhaust Gas. Journal of Electronic Materials. 2011;40. Available from: https://doi.org/10.1007/s11664-011-1569-1.

12. Liu C, Chen P, Li K. A $1 \mathrm{~kW}$ Thermoelectric Generator for Lowtemperature Geothermal Resources. in Proceedings, ThirtyNinth Workshop on Geothermal Reservoir Engineering, Stanford University, Stanford, California. 2014;.

13. Vu LQ. The study on making thermoelectric generator using heat energy from the engine exhaust. Master Thesis, Ho
Chi Minh City University of Technology and Education, Ho Chi Minh. 2014;.

14. Aranguren P, Astrain D, Rodríguez A, Martínez A. Experimental investigation of the applicability of a thermoelectric generator to recover waste heat from a combustion chamber. Applied Energy. 2015;152:121-130. Available from: https://doi. org/10.1016/j.apenergy.2015.04.077.

15. Zhang Y, Cleary M, Wang X, Kempf N, Schoensee L, Yang J, et al. High-temperature and high-power-density nanostructured thermoelectric generator for automotive waste heat recovery. Energy Conversion and Management. 2015;105:946950. Available from: https://doi.org/10.1016/j.enconman.2015. 08.051.

16. Jeng TM, Tzeng SC, Yang BJ, Li YC. Design, Manufacture and Performance Test of the Thermoelectric Generator System for Waste Heat Recovery of Engine Exhaust. Inventions . 2016;2016:1-2. Available from: https://doi.org/10.3390/ inventions1010002.

17. Remeli MF, Date A, Orr B, Ding LC, Singh B, Affandi NDN, et al. Experimental investigation of combined heat recovery and power generation using a heat pipe assisted thermoelectric generator system. Energy Conversion and Management. 2016;111:147-157. Available from: https://doi.org/10.1016/j. enconman.2015.12.032.

18. Kim TY, Negash AA, Cho G. Waste heat recovery of a diesel engine using thermoelectric generator equipped with customized thermoelectric modules. Energy Conversion and Management. 2016;124:280-286. Available from: https://doi. org/10.1016/j.enconman.2016.07.013.

19. Fernádez-Yánez $P$, Armas $O$, Kiwan $R$, Stefanopoulou AG, Boehman AL. A thermoelectric generator in exhaust systems of spark-ignition and compression-ignition engines. A com- 

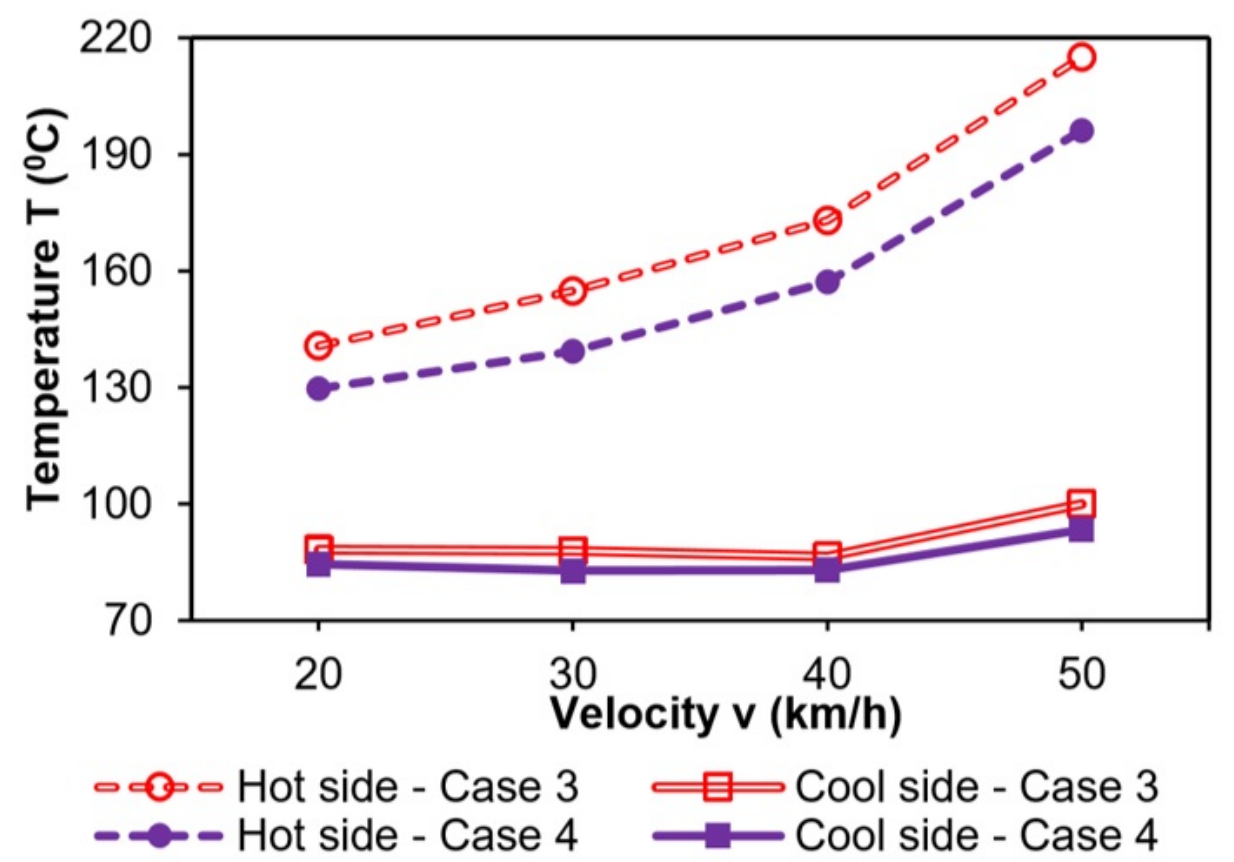

Figure 16: Characteristics of hot side temperature and cool side temperature correspond to vehicle speed in case (3) and case (4)

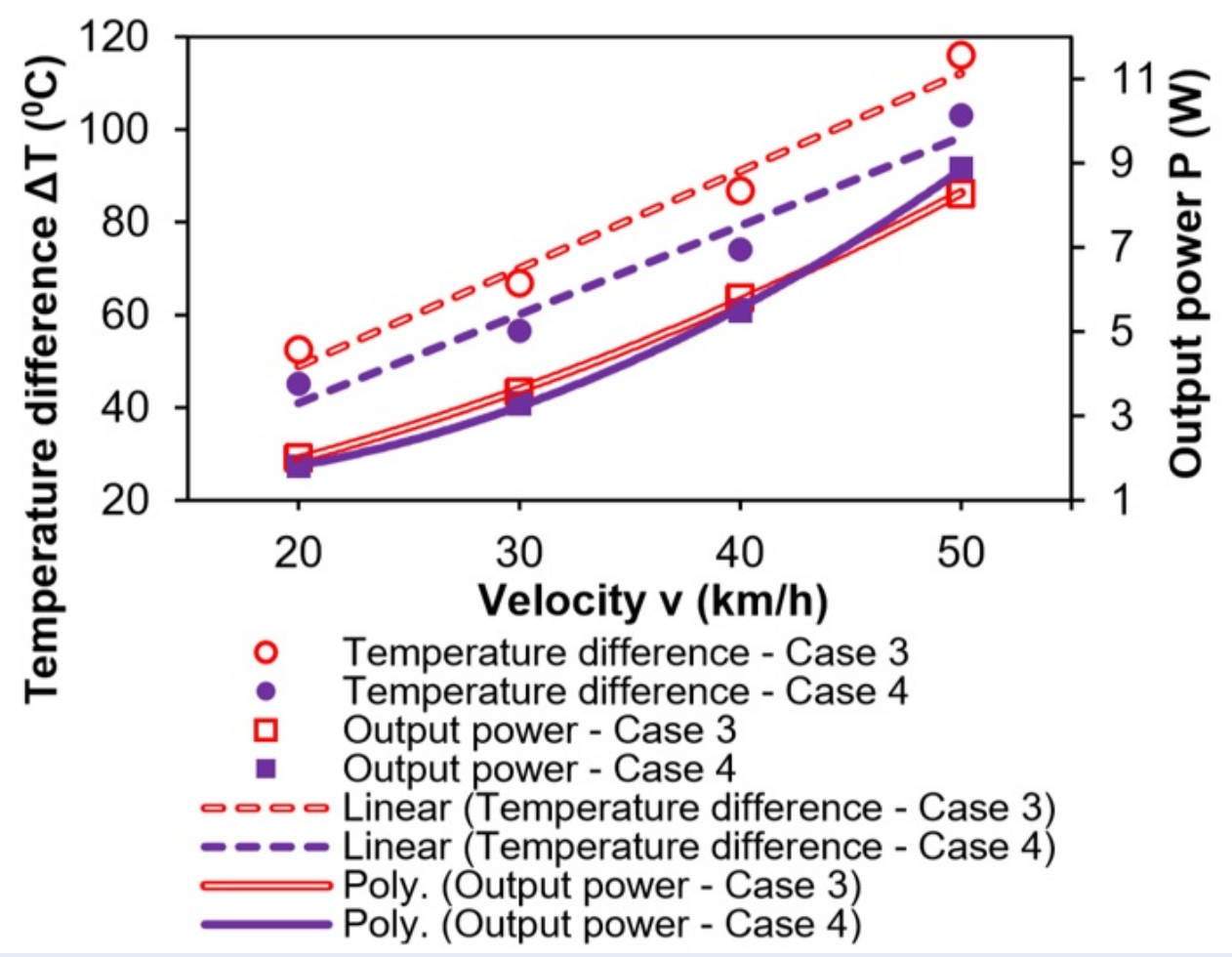

Figure 17: Characteristics of output power and temperature difference between the hot and cool side correspond to vehicle speed in case (3) and case (4) 
parison with an electric turbo-generator. Applied Energy. , vol , pp -, . 2018;229:80-87. Available from: https://doi.org/ 10.1016/j.apenergy.2018.07.107.

20. Khan MQ, Malarmannan S, Manikandaraja G. Power generation from waste heat of vehicle using thermoelectric generator: A review. in International Conference on Advances in Mechanical Engineering. 2018;

21. Rana S, Date A, Iqbal A, Akbarzadeh A. Optimization model for power generation using thermoelectric generator. Energy Procedia. 2019;160:723-730. Available from: https://doi.org/ 10.1016/j.egypro.2019.02.187.

22. Marvão, Coelho PJ, Rodrigues HC. Optimization of a thermoelectric generator for heavy-duty vehicles. Energy Conversion and Management. 2019;179:178-191. Available from: https://doi.org/10.1016/j.enconman.2018.10.045.

23. Thong HD, Hiu NV, Khoi TQ, Quan NPT, Toai HC, Khiem TT. Preliminare Study on a Prototype of Thermoelectric Generator Utilizing the Waste Heat Energy from Motorcycles. in The 11th SEATUC Symposium, HCMUT, VNU-HCM, Vietnam. 2017;
24. Thong HD, Quan NPT, Dung DM, Tinh MV, Khoi TQ, Minh PQ. Matlab Software Application to Build Heat Transfer Calculation Model for Thermoelectric Generator Unit Using Heat Source from Exhaust Gas of Motorcycle," in Proceedings of the 6th Symposium on Transportation Engineering for Young Scientists, HCMUT, VNU-HCM, Vietnam. 2018;.

25. Thong HD, Tinh MV, Khoi TQ, Dung DM, Quan NPT, Minh PQ, et al. Simulation Research and Experimental Experience of Hot Side Temperature and Cool Side Temperature of Thermoelectric Generator Unit Using Heat Source from Exhaust Gas of Motorcycle," in Proceedings of the 6th Symposium on Transportation Engineering for Young Scientists, HCMUT, VNU-HCM, Vietnam. 2018;.

26. Thong HD, Phat VT, Khoi TQ, Tinh MV, Quan NPT, Minh PQ et al. An Experimental Study on the Effect of Structure of Hot Side and Cool Side Heatsink to Performances of Thermoelectric Generator Unit Using Heat Source from Exhaust Gas of Motorcycle. Journal Of Technical Education Science. 2019;52. 


\title{
Khảo sát sự ảnh hưởng của nhiệt lượng trong hệ thống xả đến đặc tính của bộ phát nhiệt điện
}

\author{
Hồng Đức Thông ${ }^{1,2, *}$, Nghiêm Phan Thiện Quân ${ }^{1,2}$, Mai Văn Tình ${ }^{1,2}$
}

${ }^{1}$ Bộ môn Kỹ thuật Ô tô, Khoa Kỹ Thuật Giao Thông, Trường Đai học Bách Khoa TP. HCM, Viẹt Nam

${ }^{2}$ Đại học Quốc gia Thành phố Hồ Chí Minh, Việt Nam

Liên hệ

Hồng Đức Thông, Bộ môn Kỹ thuật Ô tô, Khoa Kỹ Thuật Giao Thông, Trường Đại học Bách Khoa TP. HCM, Việt Nam

Đại học Quốc gia Thành phố Hồ Chí Minh, Việt Nam

Email: hongducthong@hcmut.edu.vn

Lịch sử

- Ngày nhận: 20-8-2019

- Ngày chấp nhận: 30-12-2020

- Ngày đăng: 22-01-2021

DOI : 10.32508/stdjet.v3iSI2.558

\section{Check for updates}

\section{Bản quyền}

๑ Đ ĐHQG Tp.HCM. Đây là bài báo công bố mở được phát hành theo các điều khoản của the Creative Commons Attribution 4.0 International license.

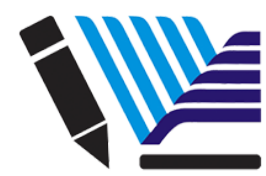

VNU-HCM Press

\section{TÓM TẮT}

Nghiên cứu này khảo sát ảnh hưởng của nhiệt lượng truyền từ hệ thống xả xe gắn máy vào môi trường đến đặc tính hoạt động của bộ phát điện nhiệt điện. Nhiệt lượng này được thay đổi bằng cách bọc cách nhiệt bên ngoài hệ thống xả và thay đổi diện tích thu nhiệt của bộ phát nhiệt điện. Bộ phát nhiệt điện bao gôm 8 mồ-đun nhiệt điện và chúng hấp thụ nhiệt năng từ khí thải để sinh ra điện. Bộ phát nhiệt điện được gắn trên bộ giảm âm tùy chỉnh của xe Suzuki Sapphire 125 và được thử nghiệm ở dải tốc độ từ $20 \mathrm{~km} / \mathrm{h}$ đến $50 \mathrm{~km} / \mathrm{h}$. Kết quả thực nghiệm cho thấy nhiệt lượng ảnh hưởng đến nhiệt độ và công suất phát của bộ phát nhiệt điện. Việc giảm lượng nhiệt này làm giảm nhiệt độ mặt lạnh thông qua việc hạn chế hiện tượng sấy nóng không khí làm mát và tăng nhiệt độ mặt nóng của bộ phát nhiệt điện do việc giảm tổn thất nhiệt. Hai hiệu ứng này dẫn đến sự gia tắng chênh lệch nhiệt độ giữa hai bề mặt của thiết bị nhiệt điện; do đó, công suất phát tăng. Sự khác biệt về công suất phát giữa các trường hợp thử nghiệm có thể đạt tới 54\%. Bên cạnh đó, phần nhiệt lượng thất thoát tại ống dẫn khí thải có ảnh hưởng đến cả nhiệt độ và công suất phát của bộ phát nhiệt điện tại dải vận tốc thử nghiệm thấp và trung bình. Tuy nhiên, ở dải vận độ cao, nhiệt lượng tỏa ra ở ống dẫn khí thải gần động cơ ảnh hưởng không đáng kể đến công suất đâuu ra của bộ phát nhiệt điện. Tóm lại, thông qua việc giảm nhiệt lượng truyển từ hệ thống xả vào môi trường, bộ phát nhiệt điện có thể nhanh chóng đạt trạng thái làm việc ổn định và tăng công suất phát. Tuy nhiên, việc giảm nhiệt lượng này quá mức có thể dẫn đến sự quá nhiệt ở bể mặt nóng của bộ phát nhiệt điện, từ đó làm hỏng các thiết bị nhiệt điện và làm giảm hiệu suất của bộ phát nhiêt điên.

Từ khoá: Nhiệt lượng, nhiệt độ, công suất phát, bộ phát nhiệt điện 